\title{
Response of Asiatic Lilium Hybrid cv. Tresor to Foliar Application of Different Group of Nutrients
}

\author{
Tapan Kumar Giri ${ }^{1 *}$, Sashikala Beura ${ }^{2}$, Swarnasarika Behera $^{3}$ and Souradeep Acharjee ${ }^{1}$ \\ ${ }^{1}$ Department of Floriculture and Landscaping, OUAT, Bhubaneswar, Odisha, India \\ ${ }^{2}$ Department of Floriculture and Landscaping and Director, BTCC, OUAT, Odisha, India \\ ${ }^{3}$ Department of Horticulture, Palli Sikshya Bhawan, Visva Bharti, West Bengal, India \\ *Corresponding author
}

K e y w o r d s
$\begin{aligned} & \text { Asiatic, Foliar, } \\ & \text { Lilium, Nutrient, } \\ & \text { Quality. }\end{aligned}$
Article Info
$\begin{aligned} & \text { Accepted: } \\ & 10 \text { July } 2017 \\ & \text { Available Online: } \\ & \text { 10 September } 2017\end{aligned}$

\section{Introduction}

Lily (Lilium spp.) is an excellent cut flower and ranks $4^{\text {th }}$ in the global trade (Desh raj-2015). It is a species of great economic importance in production and commercialization of cut flower in the international market (Jimenez et al., 2012). Due to its size, beauty and longevity Lilium is one of the ten most superior cut flowers in the world (Thakur et al., 2005). This highly prized cut flower is among the most beautiful and elegant looking flowers, which makes it popular for different occasions, whether it is for alleviating a sad soul or for a joyous occasion like wedding.
Now a day a bouquet without a lily seems incomplete. Due to its increasing consumer preference its market is growing vigorously not only in India, but also in state like odisha. High quality fresh cut lilies have a distinct competitive edge over lilies from out of state. Proper plant nutrition is essential for successful production of floricultural crops in open and also under protected conditions. Quality is one of the most important characters in the cut flower industry and this is influenced by application of nutrients. To reach out the competitive export and domestic 
markets, quality plays a vital role. Integrated supply of micronutrients with macronutrients in adequate amount and suitable proportions is one of the most important factors that control the plant growth in flower crops. So this experiment was carried with the objectives to study the impact of foliar application of nutrients on vegetative growth, flowering behaviour, post-harvest and bulb production of Asiatic lilium hybrid cv. Tresor.

\section{Materials and Methods}

The research work was carried out under the shade net structure of RKVY project at Biotechnology and Tissue Culture Centre (BTCC), Orissa University of Agriculture and Technology Bhubaneswar, Odisha during the year 2014-16. Lilium hybrid Tresor was taken as experiment material. Experiment was laid out with 8 treatments and 4 replications and each replication having 3 plants planted in pots with a media mixture of FYM, cocopeat and garden soil in equal proportion. They were supplemented with a common dose of starter fertilizer in equal quantities invariable of treatments. Plants were treated with MS macro nutrient, MS micro nutrient and MS Vitamins solution either alone or in combinations for this experiment. Data was collected for various qualitative and quantitative parameters and was analysed using Completely Randomized Design (CRD). The nutrient solution used for experiment is cited below (Gomez and Gomez, 1984).

MS Macro nutrient solution (Hi- Media- TS 1068-10) applied @ $100 \mathrm{ml} / \mathrm{L}$ where Potassium Nitrate@ $1900 \mathrm{mgl}^{-1}$, Ammonium Nitrate@1650 mgl ${ }^{-1}$, Calcium Chloride@ $440 \mathrm{mgl}^{-1}$, Potassium Di Hydrogen phosphate @ $170 \mathrm{mgl}^{-1}$ and Magnesium sulphate @ 370 $\mathrm{mgl}^{-1}$ were used.

MS Micro nutrient solution@10 $\mathrm{mll}^{-1}$ was applied, where the microelements viz.
Manganese sulphate @ 16.9 ppm, Boric acid @ 6.2 ppm, Potassium Iodide @ 0.83 ppm, Zinc Sulphate @ 8.6 ppm, Copper sulphate @ $0.03 \mathrm{ppm}$, Ammonium Molebedate with Ferrous sulphate@27.8 ppm mixed with Luke warm water were used.

MS Vitamins like Glycine @ 2.0 ppm, Nicotinic acid @ 0.5 ppm, Thiamine HCl @ 0.1 ppm, Pyrodoxine $\mathrm{HCl} @ 0.5$ ppm were used and applied @ $1 \mathrm{mll}^{-1}$.

These materials were used in the treatments either alone or in combinations. Observations on growth parameters, flower bud, flower, vase life of flower and bulb were recorded.

\section{Results and Discussion}

\section{Impact of nutrients on vegetative growth of lilium hybrid cv. Tresor (Table 1)}

The data revealed that foliar application of MS Macro nutrient solution and Vitamins in combination $\left(\mathrm{T}_{6}\right)$ significantly increased the plant height $(70.83 \mathrm{~cm})$ which was statistically at par with $\left(\mathrm{T}_{8}\right)$ the combination of all MS Macro, MS Micro and MS Vitamins $(69.58 \mathrm{~cm})$, whereas minimum growth $(61.15$ $\mathrm{cm})$ was observed in the control plot $\left(\mathrm{T}_{1}\right)$ which was sprayed only with water. Foliar application of MS Micro $\left(\mathrm{T}_{3}\right)$ significantly enhanced the number of leaves (88.38) which stood almost at par with $\mathrm{T}_{5}(88.00)$ and all other treatments except control $\left(\mathrm{T}_{1}\right)$, which was found to be the lowest (78.90). The leaf length was found to be significantly maximum $(11.87 \mathrm{~cm})$ in the treatment $\mathrm{T}_{6}(\mathrm{MS}$ Macro + Vitamins) which was at par with $\mathrm{T}_{8}$ $(11.53 \mathrm{~cm})$.

The maximum leaf width $(1.40 \mathrm{~cm})$ was observed in the same treatment $\mathrm{T}_{6}$ (MS Macro + MS Vitamins) which were significantly more than all other treatments. Considering the Basal stem diameter the plants receiving with all the nutrients and vitamins $\left(\mathrm{T}_{8}\right)$ 
exhibited the maximum stem diameter (1.95 $\mathrm{cm}$ ) which was at par with $\mathrm{T}_{5}$ (MS Macro + MS Micro) $(1.88 \mathrm{~cm})$ and $\mathrm{T}_{6}$ (MS Macro + MS Vitamins) $(1.85 \mathrm{~cm})$.

The effect of MS macro played a significant role in developing healthy vegetation here. All the treatments consisting MS Macro nutrient solution had better vegetation than others. Nitrogen being important in cell division and vegetative growth resulted better plant height. Its combining effect with calcium and other macro nutrients utilizes vitamins in better proportion and catalyzes enzymatic activity for greater vegetation.

Phosphorous works as the energy currency in plants and potash helps to build a strong framework of plant. Magnesium is the central atom of chlorophyll and helps photosynthesis. Sulphur is the Ingredient of amino acids and enzymes. In plants thiamine is found in large quantities in actively growing regions. It is synthesized in leaves in the presence of light and then translocates to other regions preferably to growing regions. Nicotinic acid is found in leaves and green stems. As roots cannot synthesize niacin and its derivates, it is imported from aerial leaves. It is believed that it is synthesized from a precursor called tryptophan, which is also a precursor for IAA. So exogenous application of combination of all these resulted a better vegetation than others. This result coincides with the research findings of Muneeb et al., (2015), Calcium nitrate significantly improved plant height, leaf area (LA) and LA index (LAI) in lilium cv. Sereda and Navona. Neerja et al., (2005) reported the response of cultivars towards the different levels of nitrogen in increasing the number of leaves plant-1. Nitrogen at 20 $\mathrm{g} / \mathrm{m} 2$ was reported to increase the number of leaves in lilium cultivars "Elite." Salazar et al., (2011) also reported improved LA under calcium nitrate regime in lilium cultivars "rio negro." Also reported optimum plant height and stem diameter in plants fed with higher calcium concentration.

Impact of nutrients on flower bud characteristics of lilium hybrid cv. Tresor. (Table 2)

The plants receiving the foliar application of all nutrients and vitamins $\left(\mathrm{T}_{8}\right)$ had the minimum gestation period and days taken for flower bud appearance was significantly lower in it (18.67) and it was at par with $\mathrm{T}_{3}$ (19.00), $\mathrm{T}_{7}$ (19.08) and $\mathrm{T}_{5}$ (19.25) whereas longest gestation period (21.5) was observed in the control plot $\left(\mathrm{T}_{1}\right)$. Earliest colour break of buds was observed in the treatments sprayed with MS Micro + MS Vitamins $\left(\mathrm{T}_{7}\right)$ (32.99 days) which was found to be at par with $\mathrm{T}_{3}$ (MS Micro) (33.2 days) and the longest time for colour break was counted (39.8) in the control plot $\left(\mathrm{T}_{1}\right)$. Foliar application of MS Micro + MS Vitamins $\left(\mathrm{T}_{7}\right)$ significantly advanced the days to bud break (36.13 days) which was statistically at par with $\mathrm{T}_{3}$ (MS Micro) (37.28 days) and T8 (application of all nutrients and vitamins) (38.44 days). In terms of Number of flower buds, $\mathrm{T}_{7-}$ combination of MS Micro and MS Vitamins exhibited significantly the highest number (3) which is statistically at par with $\mathrm{T}_{8}$ (Combination of MS Macro, Micro and Vitamins) (2.92), $\mathrm{T}_{5}$ (2.58) and $\mathrm{T}_{3}$ (2.45). Flower bud length was significantly increased in $\mathrm{T}_{8}$ (plants receiving the Combination of MS Macro, Micro and Vitamins) $(8.78 \mathrm{~cm})$ which was $12.94 \%$ higher than the control $(6.78 \mathrm{~cm})$. Similarly Flower bud width was found to be the maximum in the same treatment $\mathrm{T}_{8}(4.25 \mathrm{~cm})$ which was significantly different from all other treatments and the flower buds of the control plots have shown the lowest bud width (3.05 $\mathrm{cm})$.

On bud duration parameter the control plot showed the maximum bud duration (22.73) and the plants receiving all the nutrients $\left(\mathrm{T}_{8}\right)$ 
had the least duration of buds (19.36) significantly, which was statistically at par with $\mathrm{T}_{7}$ (19.71) and $\mathrm{T}_{3}$ (19.78). The application of MS Macro + MS Micro + MS Vitamins exhibited better results on all flower bud characteristics of Lilium hybrids cv. Tresor which advanced the days to flower bud appearance (18.67), maximized flower bud length $(8.78 \mathrm{~cm})$, flower bud width $(4.25 \mathrm{~cm})$ and minimized bud duration (19.36 days) and was at par with the best treatment in terms of number of flower buds (2.92). But days to colour break (32.99 days) and days to bud break (36.13 days) from planting was fastened with the treatments of MS Micro + MS Vitamins.

Table.1 Impact of nutrients on vegetative parameters of lilium hybrid cv. Tresor

\begin{tabular}{|l|l|l|l|l|l|l|}
\hline $\begin{array}{l}\text { Trt. } \\
\text { No. }\end{array}$ & Parameters & $\begin{array}{l}\text { Plant } \\
\text { height } \\
(\mathrm{cm})\end{array}$ & $\begin{array}{l}\text { No of } \\
\text { leaves }\end{array}$ & $\begin{array}{l}\text { Leaf } \\
\text { length } \\
(\mathrm{cm})\end{array}$ & $\begin{array}{l}\text { Leaf } \\
\text { width } \\
(\mathrm{cm})\end{array}$ & $\begin{array}{l}\text { Basal } \\
\text { stem } \\
\text { diameter } \\
(\mathrm{cm})\end{array}$ \\
\hline T1 & Control & 61.13 & 78.90 & 10.72 & 0.95 & 1.13 \\
\hline T2 & MS macro & 66.04 & 81.63 & 11.26 & 1.15 & 1.80 \\
\hline T3 & MS micro & 66.04 & 88.38 & 10.74 & 1.14 & 1.35 \\
\hline T4 & MS Vitamins & 64.73 & 87.00 & 10.87 & 1.17 & 1.40 \\
\hline T5 & MS macro + MS micro & 67.08 & 88.00 & 11.50 & 1.04 & 1.88 \\
\hline T6 & MS macro + MS vitamins & 70.83 & 85.38 & 11.87 & 1.40 & 1.85 \\
\hline T7 & MS micro + MS vitamins & 67.50 & 85.13 & 11.19 & 1.02 & 1.65 \\
\hline T8 & MS (macro + micro + vitamins) & 69.58 & 81.50 & 11.53 & 1.22 & 1.95 \\
\hline & SE(m) \pm & $\mathbf{1 . 1 0}$ & $\mathbf{1 . 9}$ & $\mathbf{0 . 1 5}$ & $\mathbf{0 . 0 5}$ & $\mathbf{0 . 0 4}$ \\
\hline & CD at 5\% & $\mathbf{3 . 2 2}$ & $\mathbf{5 . 8 4}$ & $\mathbf{0 . 4 5}$ & $\mathbf{0 . 1 5}$ & $\mathbf{0 . 1 3}$ \\
\hline
\end{tabular}

Table.2 Impact of nutrients on bud characteristics of lilium hybrid cv. Tresor

\begin{tabular}{|c|c|c|c|c|c|c|c|c|}
\hline $\begin{array}{l}\text { Trt. } \\
\text { No }\end{array}$ & Treatments Parameters & $\begin{array}{l}\text { Days to bud } \\
\text { appearance }\end{array}$ & $\begin{array}{l}\text { Days to } \\
\text { colour } \\
\text { break }\end{array}$ & $\begin{array}{l}\text { Days to } \\
\text { bud } \\
\text { break }\end{array}$ & $\begin{array}{l}\text { No of } \\
\text { flower } \\
\text { buds }\end{array}$ & $\begin{array}{l}\text { Bud } \\
\text { length } \\
\text { (cm) }\end{array}$ & $\begin{array}{l}\text { Bud } \\
\text { width } \\
(\mathrm{cm})\end{array}$ & $\begin{array}{l}\text { Bud } \\
\text { duration } \\
\text { (days) }\end{array}$ \\
\hline T1 & Control & 21.50 & 39.48 & 41.98 & 1.67 & 6.78 & 3.05 & 22.73 \\
\hline $\mathrm{T} 2$ & MS macro & 21.17 & 38.89 & 41.56 & 2.25 & 7.27 & 3.93 & 22.64 \\
\hline T3 & MS micro & 19.00 & 33.20 & 37.28 & 2.42 & 7.53 & 3.18 & 19.78 \\
\hline $\mathrm{T} 4$ & MS Vitamins & 20.75 & 37.63 & 40.68 & 2.25 & 7.63 & 3.58 & 22.18 \\
\hline T5 & MS macro + MS micro & 19.25 & 37.18 & 38.83 & 2.58 & 7.96 & 3.88 & 19.83 \\
\hline T6 & $\begin{array}{l}\text { MS macro + MS } \\
\text { vitamins }\end{array}$ & 20.08 & 37.49 & 40.09 & 2.17 & 8.37 & 3.83 & 21.34 \\
\hline $\mathrm{T} 7$ & MS micro + MS vitamins & 19.08 & 32.99 & 36.13 & 3.00 & 8.03 & 3.45 & 19.71 \\
\hline \multirow[t]{3}{*}{$\mathrm{T} 8$} & $\begin{array}{l}\text { MS (macro + micro + } \\
\text { vitamins) }\end{array}$ & 18.67 & 36.38 & 38.44 & 2.92 & 8.78 & 4.25 & 19.36 \\
\hline & SE(m) \pm & 0.25 & 0.70 & 0.74 & 0.26 & 0.12 & 0.11 & 0.28 \\
\hline & CD at $5 \%$ & 0.76 & 2.15 & 2.28 & 0.75 & 0.35 & 0.33 & 0.86 \\
\hline
\end{tabular}


Table.3 Impact of nutrients on flower characteristics of lilium hybrid cv. Tresor

\begin{tabular}{|c|c|c|c|c|c|c|c|c|c|}
\hline Trt no & $\underbrace{\text { Parameter }}_{\text {Treatment }}$ & $\begin{array}{l}\text { Planting to } \\
\text { first } \\
\text { flowering }\end{array}$ & $\begin{array}{l}\text { Colour break } \\
\text { to first } \\
\text { flowering }\end{array}$ & $\begin{array}{l}\text { Bud break to } \\
\text { first } \\
\text { flowering }\end{array}$ & $\begin{array}{l}\text { Stalk } \\
\text { length } \\
(\mathrm{cm})\end{array}$ & $\begin{array}{l}\text { Flower } \\
\text { length } \\
(\mathrm{cm})\end{array}$ & $\begin{array}{l}\text { Flower } \\
\text { width } \\
(\mathrm{cm})\end{array}$ & $\begin{array}{l}\text { Bloom life } \\
\text { of individual } \\
\text { flower } \\
\text { (days) }\end{array}$ & $\begin{array}{l}\text { Bloom life } \\
\text { of whole } \\
\text { spike } \\
\text { (days) }\end{array}$ \\
\hline T1 & Control & 43.75 & 4.28 & 1.77 & 6.04 & 7.00 & 14.63 & 5.20 & 12.17 \\
\hline $\mathrm{T} 2$ & MS macro & 43.09 & 4.20 & 1.53 & 6.90 & 7.98 & 15.67 & 5.83 & 14.08 \\
\hline T3 & MS micro & 39.50 & 6.30 & 2.23 & 6.40 & 8.04 & 14.71 & 5.45 & 12.83 \\
\hline $\mathrm{T} 4$ & MS Vitamins & 42.25 & 4.63 & 1.58 & 7.13 & 8.48 & 15.21 & 5.35 & 12.92 \\
\hline T5 & MS macro + MS micro & 41.25 & 4.08 & 2.42 & 7.21 & 8.42 & 15.50 & 6.45 & 14.25 \\
\hline T6 & MS macro + MS vitamins & 41.84 & 4.35 & 1.74 & 6.86 & 9.07 & 16.00 & 6.00 & 14.17 \\
\hline $\mathrm{T} 7$ & MS micro + MS vitamins & 38.50 & 5.51 & 2.38 & 7.57 & 8.68 & 15.54 & 5.70 & 13.34 \\
\hline \multirow[t]{3}{*}{ T8 } & $\begin{array}{l}\text { MS (macro + micro + } \\
\text { vitamins) }\end{array}$ & 40.75 & 4.38 & 2.31 & 7.35 & 9.50 & 16.75 & 6.40 & 14.84 \\
\hline & $\mathrm{SE}(\mathrm{m}) \pm$ & 0.72 & 0.13 & 0.12 & 0.27 & 0.10 & 0.35 & 0.07 & 0.19 \\
\hline & CD at $5 \%$ & 2.22 & 0.39 & 0.36 & 0.78 & 0.29 & 1.03 & 0.21 & 0.54 \\
\hline
\end{tabular}

Table.4 Impact of nutrients on post-harvest and bulb characteristics of lilium hybrid cv. Tresor

\begin{tabular}{|c|l|c|c|c|c|}
\hline $\begin{array}{c}\text { Trt } \\
\text { no. }\end{array}$ & Treatment Parameter & $\begin{array}{c}\text { Vase life of } \\
\text { flower(days) }\end{array}$ & $\begin{array}{c}\text { Bulb } \\
\text { weight }(\mathrm{g})\end{array}$ & $\begin{array}{c}\text { Bulb } \\
\text { circumference } \\
(\mathrm{cm})\end{array}$ & $\begin{array}{c}\text { No of } \\
\text { effective roots }\end{array}$ \\
\hline T1 & Control & 6.92 & 27.70 & 12.23 & 8.25 \\
\hline T2 & MS macro & 10.83 & 33.70 & 14.38 & 11.92 \\
\hline T3 & MS micro & 8.00 & 29.83 & 13.55 & 8.75 \\
\hline T4 & MS Vitamins & 7.25 & 30.48 & 13.30 & 9.08 \\
\hline T5 & MS macro + MS micro & 10.33 & 34.13 & 14.63 & 12.92 \\
\hline T6 & MS macro + MS vitamins & 9.33 & 34.13 & 13.38 & 12.00 \\
\hline T7 & MS micro + MS vitamins & 8.33 & 31.38 & 12.53 & 10.17 \\
\hline T8 & MS (macro + micro + vitamins) & 10.17 & 34.83 & 14.68 & 12.84 \\
\hline & SE(m) & $\mathbf{0 . 1 6}$ & $\mathbf{1 . 0 9}$ & $\mathbf{0 . 3 3}$ & $\mathbf{0 . 1 9}$ \\
\hline & CD at 5\% & $\mathbf{0 . 4 6}$ & $\mathbf{3 . 1 8}$ & $\mathbf{0 . 9 5}$ & $\mathbf{0 . 5 5}$ \\
\hline
\end{tabular}


This may be due to the combine effect of all micro nutrients which result in more no of flowers and advanced the flowering. Zinc is an essential constituent of several important enzyme systems in plants. It controls the synthesis of indole acetic acid, an important plant growth regulator. Iron serves as an activator for biochemical processes, such as respiration, photosynthesis, and symbiotic nitrogen fixation. Copper serves as an activator of numerous plant enzymes. Manganese serves as an activator for enzymes in plant growth processes. Boron functions in the differentiation of meristematic cells. All these nutrients along with the vitamins resulted in faster metabolism and earliness in flowering. Similar results were obtained by Khosa et al., (2011) who reported that application of micro nutrient solution decreases the number of days of flower emergence in Gerbera.

\section{Effect of nutrients on flowering of lilium hybrid cv. Tresor. (Table 3)}

The result from the above findings pursued that the plants treated with MS Micro + MS Vitamins, significantly advanced the opening of first flower from planting (38.5 days), delayed the bud break to flowering (2.42 days) and followed the best treatment in terms of colour break to flowering (5.51 days). Maximum Stalk length $(7.57 \mathrm{~cm})$ was observed in this treatment and found to be at par with application of MS Macro + MS Micro + MS Vitamins. Similarly T8 was proved to be the best in all the flowering characters like Flower length $(9.5 \mathrm{~cm})$, Flower width $(16.5 \mathrm{~cm})$ and Bloom life of whole spike (14.84 days) where as it was closely at par with the best treatment in terms of Bloom life of individual flower (6.4 days). From the whole table, it was found that any treatment containing MS micro nutrient, induced earliness. Ahmad and co-workers (2010) also reported that micronutrients application give early and maximum flowering/plant in Rose. As reported by Elangaivendhan et al., (2016), the foliar spray for both Zinc and Iron deficiency exhibit favourable influence on flowering parameters in spider lily, the highest flowering duration and minimum days for first flower emergence. The significant influence on flower quality parameters viz., flower stalk length, flower diameter and length of flower buds were also recorded from treatments of Micronutrient application as per soil test value. As a constituent of various enzymes, Iron plays the part of a vital catalyst in the plant. Iron acts as catalyst in the synthesis of chlorophyll molecule and helps in the absorption of other elements. It is a key element in various redox reactions of respiration, photosynthesis and reduction of nitrates and sulphates. Zinc is effective in plant nutrition for the synthesis of plant hormones and balancing intake of $\mathrm{P}$ and $\mathrm{K}$ inside the plant cells. Zinc also increases the green pigments of necrotic leaf of plants. Copper is essential for photosynthesis and mitochondrial respiration, for carbon and nitrogen metabolism, for oxidative stress protection, and is required for cell wall synthesis.

Efficacy of nutrients on post-harvest and bulb production of lilium hybrid cv. Tresor (Table 4)

Vase life of the flowers was significantly the best in $\mathrm{T}_{2}$; Plants sprayed with only MS Macro (10.83 days) and the vase life of the control flowers was the lowest (6.92days). The macro nutrient contains Calcium, which played an important role in extending the vase life. Calcium being the building blocks of cell wall protects the tissues from spoilage resulting better shelf life. Similar results were obtained from different researchers. Calcium enhanced life cycle of flowers of cut lilium grown hydroponically as reported by Seyedi et al., (2013) with the use of calcium in nutrition. The use of calcium nitrate and calcium chloride increase calcium concentration in aerial organs including the stem tissues which has a direct effect on increasing the life cycle of the flowers after harvesting (Buchanan et al., 2000).

On Bulb weight characteristics the plants receiving all the nutrients and vitamins $\left(\mathrm{T}_{8}\right)$ was found to be the highest (34.83 g) which was statistically at par with $\mathrm{T}_{6}, \mathrm{~T}_{5}(34.13 \mathrm{~g}$ both $)$ and $\mathrm{T}_{2}(33.70 \mathrm{~g})$ and the minimum weight was noticed in the control bulbs (27.7 g). Similarly bulb circumference was also observed directly proportional to bulb weight and the data revealed that $\mathrm{T}_{8}$ had the maximum bulb 
circumference $(14.68 \mathrm{~cm})$ which was Istatistically at par with $\mathrm{T}_{5}(14.63 \mathrm{~cm})$ and $\mathrm{T}_{2}$ $(14.38 \mathrm{~cm})$.

Number of effective roots per bulb was counted significantly maximum in $\mathrm{T}_{5}$ (plants treated with MS Macro + MS Micro) (12.92) which was statistically at par with $\mathrm{T}_{8}$ (12.84). Application of all the nutrients resulted in better vegetation and better accumulation of photosynthates in the bulbs. The macro nutrients like phosphorous and potash helped in greater root development and bulb enlargement respectively as their primary roles.

The results from the above study showed that Asiatic lilium hybrids require an intensive use of all nutrients for a successful cultivation and qualitative as well as quantitative production for higher remuneration.

\section{References}

Ahmad I, Aslam Khan M, Qasim M, Ahmad R, Randhawa AM. 2010. Growth, yield and quality of Rosa hybrid L. as influenced by various micronutrients. Pak J Agric Sci.47(1): 5-12

Buchanan, B.B., Gruissem, W. and Jones, R.L. 2000. Biochemistry and molecular biology of plants, American Soc. Plant Biology 152-153.

Elangaivendhan, A., Barad A V, Bhosale N and Maheta Pooja. 2016. Effect of multimicronutrient formulations on growth, flowering behaviour and yield in ratoon crop of spider lily (Hymenocallis literolis 1.) $c v$. Local. International Journal of Agriculture Sciences. 8 (46): 1929-1932.

Gomez, KA, and Gomez, AA, 1984. Completely randomized design, In: Statistical procedures for Agricultural research 2nd
Edn. Johan Wiley and Sons, New York. Pp. 20.

Jimenez, S., Plaza B M, Segura M L, Contreras, J.I. and Lao, T.M. (2012). Peat substrate reuse in Lilium "Haveltia" crop. Commun. Soil Sci. \& Plant Analysis, 43: 243-250.

Khosa, S.S., Younis A, Ravit A, Yasmeen S and Riaz A. 2011. Effect of Foliar Application of Macro and Micro Nutrients on Growth and Flowering of Gerbera jamesonii L. American-Eurasian J. Agric. \& Environ. Sci., 11 (5): 736-757

Muneeb, A., 2015. Effect of split application of ammoniacal and nitrate sources of nitrogen on lilium growth and yield. Journal of Plant Stress Physiology, 1(1): 7-12.

Neerja, R., Kumar R, Dhatt KK. 2005. Effect of nitrogen levels and growing media on growth, flowering and bulb production of Lilium cultivars. J Ornamental Hortic; 8:36-40.

Raj, D., 2015. Floriculture at a glance. Kalyani publishers. Fourth edition. 42, 91-93.

Salazar-O G, Valdez L, Tello M J, Grassotti A, Burchi $\mathrm{G}$ and Castillo-González, A.M.. (2011). Calcium affects quality and nutrition of cut lily flowers. Acta Horticulturae. 900. 113-117

Seyedi, N., Torkashvand A M, Allahyari M S. 2013. Effects of Calcium Concentration under Hydroponic Conditions on Quantitative and Qualitative Growth of Lilium. Journal of Ornamental and Horticultural Plant. 3(1):19-24.

Thakur, R., Sood, A., Nagar, P. K., Pandey, S., Sobti, R.C. and Ahuja, P.S. (2005). Regulation of growth of Lilium plantlets in liquid medium by application of paclobutrazol or ancymidol for its amenability in a bioreactor system: growth parameters. Plant Cell Rep., 25: 382-391.

\section{How to cite this article:}

Tapan Kumar Giri, Sashikala Beura, Swarnasarika Behera and Souradeep Acharjee. 2017. Response of Asiatic Lilium Hybrid cv. Tresor to Foliar Application of Different Group of Nutrients. Int.J.Curr.Microbiol.App.Sci. 6(9): 3280-3286. doi: https://doi.org/10.20546/ijcmas.2017.609.404 